\title{
PASSAGE KINETICS OF DIGESTA IN HORSES FED WITH COASTCROSS HAY GROUND TO DIFFERENT DEGREES
}

\author{
Cinética de passagem em equinos alimentados com feno \\ de coastcross em diferentes formas físicas
}

\author{
Vinicius Pimentel Silva ${ }^{1}$, Fernando Queiroz de Almeida ${ }^{3}$, Róbson Ricardo Moreira Pimentel ${ }^{2}$, \\ Fernanda Nascimento de Godoi ${ }^{2}$, Tiago Marques dos Santos ${ }^{3}$, Marcus Sandes Pires ${ }^{3}$
}

\begin{abstract}
This study was conducted to evaluate the kinetics, physicochemical characteristics and particle size of digesta in the right ventral colon (RVC) of horses fed coastcross hay ground to different degrees. Four horses fitted with cannulae in the RVC were used and were fed the following forms of hay: long, chopped, ground to $5 \mathrm{~mm}$ and ground to $3 \mathrm{~mm}$. A Latin Square $4 \mathrm{x} 4$ study design was used. Each experimental period included 10 days for diet adaptation, four days for feces collection and one day for digesta collection. The kinetics of the particulate and solute phases of digesta were evaluated based on the mean retention time (MRT), passage rate $(\mathrm{k})$ and transit time (TT) using two external markers: Cr-NDF and Co-EDTA. The TT of solid phase digesta was 3 hours longer $(\mathrm{P}<0.05)$ for ground hay than with the other physical forms of hay. There was no difference $(\mathrm{P}>0.05)$ in $\mathrm{k}$ or $\mathrm{MRT}$ in either the liquid or solid phase of digesta as a function of the different degrees of hay grinding. However, the liquid phase of digesta presented a higher $\mathrm{k}$ than the solid phase, with values of 3.28 and $2.73 \mathrm{~h}^{-1}$ being obtained, respectively. The smallest particle size and the lowest neutral detergent fiber contents in colon digesta were observed when hay ground to $3 \mathrm{~mm}$ was offered, leading to values of $0.51 \mathrm{~mm}$ and $53.46 \%$, respectively. Grinding the hay increased the transit time of the liquid phase in the digestive tract of the horses, whereas no change in the kinetics of the solid phase digesta was observed. The grinding of hay reduced the NDF and the average particle size in the right ventral colon.
\end{abstract}

Index terms: Chromium, digestion, particle size, passage rate.

\begin{abstract}
RESUMO
Este trabalho teve como objetivos avaliar a cinética de passagem da digesta, as características físico-químicas e o tamanho da partícula da digesta do cólon ventral direito (CVD) de equinos alimentados com feno de coastcross com diferentes tamanhos de partículas. Utilizaram-se quatro equinos fistulados CVD alimentados exclusivamente com feno de coastcross: inteiro; feno picado, moído $(5 \mathrm{~mm})$ e moído $(3 \mathrm{~mm})$. Utilizou-se o delineamento em quadrado latino 4x4. Cada período experimental teve 10 dias de adaptação às dietas, quatro dias de coleta de fezes e um dia de coleta do conteúdo do cólon. A cinética de passagem da fase sólida e líquida da digesta no trato digestório foi estimada através do tempo médio de retenção (TMR), da taxa de passagem (k) e do tempo de trânsito (TT) utilizando os indicadores: Cr-FDN e Co-EDTA. O TT da fase sólida da digesta foi maior em 3 horas $(\mathrm{P}<0,05)$ nos equinos alimentados com o feno moído, em relação às outras formas do feno. Não houve diferença $(\mathrm{P}>0,05)$ no $\mathrm{TMR}$ e $\mathrm{k}$ tanto da fase líquida quanto na sólida da digesta em função das diferentes formas físicas do feno. No entanto, houve maior velocidade de passagem da fase líquida de $3,28 \mathrm{~h}^{-1}$, comparada à fase sólida, de 2,73 $\mathrm{h}^{-1}$, em todas as dietas. Quando se forneceu feno moído a 3 $\mathrm{mm}$ foram observados o menor tamanho de partícula e o menor teor da fibra em detergente neutro na digesta do cólon, com valores de $0,51 \mathrm{~mm}$ e $53,5 \%$, respectivamente. A moagem do feno aumentou o tempo de trânsito da fase líquida no trato digestório dos equinos, sem interferir na cinética da fase sólida da digesta. A moagem do feno reduziu os teores de FDN e o tamanho médio das partículas no CVD.
\end{abstract}

Termos para a indexação: Cromo, digestão, tamanho de partícula, taxa de passagem.

\section{INTRODUCTION}

Domestication of the equine species imposed artificial management of feeding and may be the reason for the observed incidence of digestive tract diseases in these animals. The content of roughage fiber promotes the normal function of the digestive tract (Moore et al.,
2003) and prevents behavioral disturbances (NRC, 2007). According to Drogoul et al. (2000), processing roughage cannot affect the intrinsic characteristics of fiber. However, modification of the physical structure of feedstuffs by grinding and / or pelletization might help to solve bulkiness problems at equestrian centers. Still, digestive tract retention due to the physical form of the diet needs

${ }^{1}$ Universidade Federal Rural do Rio de Janeiro/UFRRJ - Animal Science Institute - BR 465 - Km 07 - Seropédica - RJ - Brasil - $23890-000$ pimentelzootec@gmail.com

2Universidade Federal Rural do Rio de Janeiro/UFRRJ - Animal Science Institute - Seropédica - RJ - Brasil

${ }^{3}$ Universidade Federal Rural do Rio de Janeiro/UFRRJ - Veterinary Institute - Horse Health Research Laboratory/EQUILAB - Seropédica - RJ - Brasil Received in june 1, 2014 and approved in august 20, 2014

Ciênc. Agrotec., Lavras, v.38, n.5, p.506-514, set./out., 2014 
to be confirmed using commercial standard ground diets, as little information on the supply of physically modified feedstuffs is available in the literature.

Hill (2007) described the effects of feedstuff processing in horse diets and suggested that the increased interest on the subject was due to the large number of horses that are kept stalled, which are fed dry forage and concentrate exclusively during most of the year. The author concluded that further studies are necessary to understand the effects of industrial processing on physical and chemical modification in the digestive tract of horses.

The passage of digesta is associated with the fermentation process occurring in the cecum-colon. The most commonly used variables in research on the kinetics of passage are the transit time (TT), passage rate $(k)$ and mean retention time (MRT) (Van Weyenberg et al., 2006).

The present study was conducted to assess the effects of feeding coastcross hay (Cynodon dactylon) subjected to different degrees of grinding on the passage kinetics of digesta in the digestive tract and on the physical and chemical characteristics of digesta in the horse colon.

\section{MATERIALS AND METHODS}

Four crossbred horses with a mean live weight of $200 \mathrm{~kg}$ and an average age of 30 months were used in this study. The animals were cannulated in the right ventral colon via surgical procedures adapted from Lowe et al. (1970). During the pre-experimental period, the animals were subjected to the same management regime. They were kept in a $3 \times 3 \mathrm{~m}$ stall and exercised daily by trotting for 30 minutes. The horses received tetanus immunization and were dewormed against ecto- and endo-parasites. A $4 \times 4$ Latin square design was used, and each experimental period lasted 15 days, including 10 days for diet adaptation and intake adjustment, four days of feces collection and one day for the collection of digesta from the ventral colon. Coastcross hay (Cynodon dactylon L.) was supplied to the animals as the exclusive diet. During the adaptation period, the animals received hay ad libitum for intake adjustment. After this period, hay was supplied at $2.5 \%$ of the horses' live weight on dry matter basis (Table 1). Water was supplied ad libitum, and a $50 \mathrm{~g} /$ animal mineral supplement was provided daily.

The experimental treatments consisted of feeding coastcross hay in four different physical forms: long hay; hay chopped to $5 \mathrm{~cm}$; ground hay ( $5 \mathrm{~mm}$ diameter sieve); and finely ground hay ( $3 \mathrm{~mm}$ diameter sieve). The chopped hay was processed in an electric forage chopper. The hay was ground in a hammer mill using sieves with mesh diameters of $5 \mathrm{~mm}$ and $3 \mathrm{~mm}$. The hay was offered in equal quantities at 01:00; 07:00; 13:00 and 19:00 h. Two external markers were used in the study to evaluate kinetics: mordent chromium in neutral detergent fiber (CrNDF), as a particulate marker, and a cobalt-EDTA complex (Co-EDTA), as a solute marker. They were prepared as reported by Udén et al. (1980). Pulse dose markers were given to animals before their meal at 7:00 a.m. on the $11^{\text {th }}$ day of each experimental period. A single pulse dose of $25 \mathrm{~g} \mathrm{Cr}-\mathrm{NDF}$ was supplied directly in the feeder, while a $3 \mathrm{~g}$ pulse dose of Co-EDTA diluted in $30 \mathrm{~mL}$ of water was administered orally with a syringe. Partial feces samples were proceeded during each experimental period; samples of approximately $200 \mathrm{~g}$ were collected from the animal's rectum at the following times: $0,4,12,16,20,24,30,36$, $42,48,54,60,66,72$ and 78 hours after the administration of markers, as described by Cuddeford et al. (1992). The feces samples were stored at $-18^{\circ} \mathrm{C}$. At the end of the experimental period, the samples were defrosted, dried in a forced air oven at $65^{\circ} \mathrm{C}$ for 48 hours and ground to $1 \mathrm{~mm}$.

The chromium and cobalt contents of the feces samples were determined as described by Bolin and King (1952) and Kimura and Miller (1957). For these assays, $0.5 \mathrm{~g}$ of each sample was placed in test tubes. The samples were kept in a unit with fume removal, and $4.0 \mathrm{~mL}$ of nitric acid was added to each tube to perform pre-digestion for 12 hours. The tubes were then shaken by hand and placed in a Kjeldahl digestion unit for $30 \mathrm{~min}$ at 80 and $90^{\circ} \mathrm{C}$ and then at $120^{\circ} \mathrm{C}$ until only 0.5 to $1.0 \mathrm{~mL}$ of the solution remained in the tube. The tubes were subsequently removed from the digestion unit and left to cool for $10 \mathrm{~min}$, after which 2.0

Table 1 - Chemical composition (\%) of coastcross hay on a dry matter basis.

\begin{tabular}{lcccccccc}
\hline Nutrients & $\mathrm{DM}^{1}$ & $\mathrm{CP}^{2}$ & $\mathrm{NDF}^{3}$ & $\mathrm{ADF}^{4}$ & $\mathrm{HEM}^{5}$ & $\mathrm{CEL}^{6}$ & $\mathrm{LIG}^{7}$ & $\mathrm{GE}^{8}$ \\
\hline $\begin{array}{l}\text { Coastcross } \\
\text { hay }\end{array}$ & 86.1 & 12.2 & 70.7 & 29.3 & 41.5 & 25.7 & 4.1 & 4.3 \\
\hline
\end{tabular}

${ }^{1} \mathrm{DM}$ : Dry matter; ${ }^{2} \mathrm{CP}$ : crude protein, ${ }^{3} \mathrm{NDF}$ : neutral detergent fiber, ${ }^{4} \mathrm{ADF}$ : acid detergent fiber, ${ }^{5} \mathrm{HEM}$ : hemicellulose, ${ }^{6} \mathrm{CEL}:$ cellulose, ${ }^{7}$ LIG: Lignin, ${ }^{8} \mathrm{GE}$ : Gross energy (Mcal/Kg of DM); Mineral supplement: Ca 180 g; P 70 g; S 12 g; Mg 10 g; Na 115 g; Fe 4,500 mg; Cu 2,000 mg; Zn 3,000 mg; Mn 1,000 mg; I 180 mg; Se 12 mg; Co 40 mg; Lys 10 g; Vit A(UI) 40 mg; Vit E (UI) 400 mg; F 700 mg. 
$\mathrm{mL}$ of perchloric acid was added to each tube. The tubes were then returned to the digestion unit and maintained at $180-190^{\circ} \mathrm{C}$ until the solution cleared, after approximately 3 hours. Following digestion, $5 \mathrm{~mL}$ of ultrapure water was added to each tube, which was then shaken, and the contents were transferred to $50 \mathrm{~mL}$ snap-cap type tubes using ultrapure water to drag all of the material and to bring the final volume to $30 \mathrm{~mL}$. The chromium and cobalt contents of the samples were analyzed in a plasma optical emission spectrometer (Optima 3000) in the Plant Analysis Laboratory at the National Soil Research Center - EMBRAPA - SOLOS.

The mean retention time (MRT) of the digesta throughout the digestive tract was calculated according to equation described by Faichney (1975) and applied to the kinetics of the excretion of Cr-NDF and Co-EDTA:

$\operatorname{MRT}($ hours $)=\frac{\sum_{i=n}^{i=n} M i x \Delta t i}{\sum_{i=1}^{i=n} M i}$

where $\Delta t i$ is the time elapsed between the introduction of the markers (time zero) and the middle of the $i$ th collection interval and is calculated as $\left(t i+t i-1 \frac{1}{2}\right)$ with, where $t i$ is the time to the end of the $i$ th interval, and Mi is the quantity of marker excreted in the $i$ th interval, with all markers being excreted by the $n$th interval.

The digesta passage rate $(k)$ throughout the digestive tract was estimated as the inverse of $k:\left(h^{-1}\right)=\frac{1}{\text { MRT }}$

The digesta transit time (TT) was considered to be the interval of time between the administration of the markers to the animals and their first appearance in the feces.

On the $15^{\text {th }}$ day of each experimental period, digesta was collected once from the right ventral colon at 9:00 a.m. A digesta sample of approximately $700 \mathrm{~g}$ was obtained from each animal. The samples were weighed, labeled and subdivided as follows: approximately $600 \mathrm{~g}$ was used to analyze nutrients and particle size, and the remainder was used for $\mathrm{pH}$ analysis.

After the end of the experimental periods, the samples were defrosted at room temperature. Subsamples of each sample of approximately $100 \mathrm{~g}$ were separated and dried in a forced air oven. The samples were then weighed and ground through a $1 \mathrm{~mm}$ sieve. These samples were used to analyze the contents of dry matter (DM), organic matter $(\mathrm{OM})$ and crude protein $(\mathrm{CP})$ according to the AOAC (1995). Neutral detergent fiber (NDF) and acid detergent fiber (ADF) were determined according to Van Soest et al. (1991). The pH of the colon contents was analyzed immediately after collection. The contents were strained through four layers of cheesecloth, and the $\mathrm{pH}$ was then immediately determined using a potentiometer.

To determine the particle size, samples of colon contents were processed according to methodology reported by Smith and Waldo (1969). Following defrosting, $300 \mathrm{~g}$ of each sample was weighed and placed in a $6 \mathrm{~L}$ receptacle, after which $200 \mathrm{~mL}$ of a neutral detergent solution and $2.5 \mathrm{~L}$ of water were added. The material was boiled for one hour, then filtered through a 0.105 to $0.074 \mathrm{~mm}$ sieve, washed in four liters of hot water and washed again in water until the water gradually cleared. The material remaining following washing and filtration was placed in a $1 \mathrm{~L}$ beaker, and $250 \mathrm{~mL}$ of ethylic alcohol was added, after which the sample was left to rest for 5 min. Then, the material was filtered again and placed in a beaker, and $250 \mathrm{~mL}$ of hexane was added. After resting for $5 \mathrm{~min}$, the hexane was drained, and the material was placed in a forced air oven to dry at $55^{\circ} \mathrm{C}$ for 72 hours. After drying, the material was wetted with a small quantity of acetone, then carefully detached and dried again. The prepared samples were sieved in an electric sieve shaker (PRODUTEST) with the rotor at position 10 using a sieving time of 10 minutes, which is sufficient to achieve stability of the contents in each sieve according to the procedures adopted by the American Dairy Science Association (1970). Sieves with mesh sizes of $0.149,0.297,0.590$, $1.190,2.380$ and $4.760 \mathrm{~mm}$, with a $20 \mathrm{~cm}$ diameter and 5 $\mathrm{cm}$ depth were used. The dry weight retained from each sieve was expressed as a percentage of the total weight retained in the six sieves, and the accumulated weight was calculated as the weight removed from one sieve added to that removed from the sieves with immediately superior pore sizes, expressed as a percentage.

The average particle size was employed to represent the particle size of the ground hay and colon digesta, calculated using the parameter of an exponential equation (Fisher et al., 1988): $\mathrm{R}=100 * \mathrm{e}^{\left(-\mathrm{K}^{*}(\mathrm{~S}-\mathrm{W})\right)}$, where $\mathrm{R}$ is the accumulated percentage of the sample dry weight per sieve; $\mathrm{S}$ is the mesh size of the sieve $(\mathrm{mm})$; $\mathrm{W}$ is the smallest estimated particle size $(\mathrm{mm})$; and $\mathrm{K}$ is the constant decline of the exponential curve, which indicates the proportion of particles above a certain mesh size that will pass through a wider mesh-size sieve. Thus, the mean particle size (MPS) was calculated as follows: MPS $=1 / \mathrm{K}$ $+\mathrm{W}$. The Rosen Brock and quasi-Newton algorithm was 
applied to fit the data to the exponential equation, using a non-linear estimation procedure from the STATISTICA package.

The mean values of the physical and chemical characteristics and the digesta particle size from the colon as well as the mean retention time, passage rate and transit time for the solid and liquid phases of digesta were subjected to variance analysis and compared via the Student-NewmanKeuls test at a $5 \%$ probability. The kinetic values for the solute and particulate phases of digesta were subjected to variance analysis and compared via Fisher's test at a 5\% probability. The statistical analyses were performed using the SAEG (Genetic and Statistical Analysis System) package.

\section{RESULTS AND DISCUSSION}

There was no effect of hay processing on the mean retention time and passage rate of the solute phase of the digesta, with mean values of $30.7 \mathrm{~h}$ and $3.78 \mathrm{~h}^{-1}$ being obtained, respectively (Table 2).

However, the TT differed $(\mathrm{P}<0.05)$ between the physical forms the hay. Hay ground to 5 or $3 \mathrm{~mm}$ was retained longer in the digestive tract, for 13 hours, compared with long or chopped hay.
The smallest particle size delayed the first appearance of the solute marker in the feces. The percent recovery of Co-EDTA was higher than $90 \%$ for the first 48 hours of collection and was close to $100 \%$ after 78 hours (Figure 1).

Pearson and Merritt (1991) evaluated the MRT of digesta in ponies fed hay or oat straw using Co-EDTA as a solute marker and obtained values of 31.3 and 34.1 hours for hay and oat straw, respectively. The observed difference was described as a diet effect. Drogoul et al. (2000) also used Co-EDTA to assess the passage of solutes in fistulated horses and reported a slower appearance of solutes when the animals received ground and pelleted hay ( 5 and $3 \mathrm{~mm}$ ) compared with chopped hay. A similar effect on the solute phase was observed in the present study only for the transit time in horses fed ground coastcross hay. However, the difference in the MRT reported by Drogoul et al. (2000), of 23.4 hours for chopped hay versus 47.7 hours for ground hay, was not found in the present study. Horses fed ad libitum with an exclusive diet composed of grass hay with a distinct nutritional composition presented MRT values of 21 to $23 \mathrm{~h}$ in a study by Clauss et al. (2014). Additionally, these authors detected differences in the kinetics of the solute phase according to the intake level, with the MRT

Table 2 - Mean values and standard deviation of the mean retention time (MRT), passage rate $(k)$ and transit time (TT) of the solute phase in horses fed coastcross hay subjected to different particle size reductions.

\begin{tabular}{lcccccc}
\hline \multirow{2}{*}{ Variables } & \multicolumn{7}{c}{ Coastcross hay } \\
\cline { 2 - 7 } & Long & Chopped $(5 \mathrm{~cm})$ & Ground $(5 \mathrm{~mm})$ & Ground $(3 \mathrm{~mm})$ & Mean & CV $(\%)$ \\
\hline MRT (hours) & $30.62 \pm 1.24$ & $31.17 \pm 3.55$ & $29.70 \pm 3.30$ & $31.37 \pm 2.01$ & 30.72 & 5.6 \\
$k\left(\mathrm{~h}^{-1}\right)$ & $3.28 \pm 0.13$ & $3.24 \pm 0.36$ & $3.39 \pm 0.37$ & $3.19 \pm 0.21$ & 3.78 & 5.4 \\
TT (hours) & $10^{\mathrm{b}}$ & $10^{\mathrm{b}}$ & $13^{\mathrm{a}}$ & $13^{\mathrm{a}}$ & - & 10.0 \\
\hline
\end{tabular}

Means followed by same letter do not differ by the SNK test $(\mathrm{P}>0.05)$.

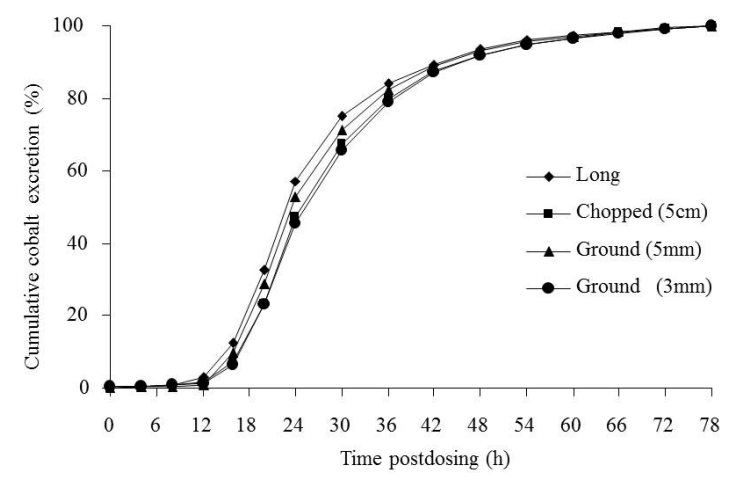

Figure 1 - Cumulative cobalt excretion (expressed as the percentage of total Co excreted) in horses fed coastcross hay subjected to different degrees of particle size reduction. 
increasing with reduced intake. In contrast, when Miyaji et al. (2014) fixed the intake of grass hay to $2.0 \%$ or 1.3 $\% \mathrm{BW} /$ day, no difference in the solute total MRT was observed.

The transit time values of 10 and 13 hours obtained for the solute phase were higher than the values reported by Oliveira et al. (2003) in horses fed coastcross hay as the exclusive diet, in which the appearance of markers was observed four hours after administration. Regarding the MRT and passage rate, the values obtained in the present study were 30.6 hours and $3.3 \mathrm{~h}^{-1}$, respectively, similar to the values of 32.8 hours and $3.1 \mathrm{~h}^{-1}$ reported by Oliveira et al. (2003).

There was no effect $(\mathrm{P}>0.05)$ of the reduction of the coastcross hay particle size on the kinetics variables recorded for the particulate phase in the digestive tract of horses under the applied experimental conditions, with mean MRT, k and TT values of $36.6 \mathrm{~h} ; 2.7 \mathrm{~h}^{-1}$ and $18.2 \mathrm{~h}$ being obtained, respectively (Table 3 ).

The recovery of the chromium marker was greater than $80 \%$ for the first 48 hours and close to $100 \%$ after 78 hours (Figure 2). Vander Noot et al. (1967) observed a mean percentage of fecal chromium recovery between diets of $84 \%$ at 48 hours after administration.
Pearson and Merritt (1991) assessed passage kinetics in ponies using Cr-NDF as a particulate marker and observed MRT values of 29.9 and 34.8 hours for hay and oat straw, respectively. Oliveira et al. (2003) fed horses with increasing levels of coastcross hay diets, and employing Cr-NDF as a marker, these authors observed an MRT of $42.3 \mathrm{~h}$ and a TT of $27 \mathrm{~h}$, which are higher values than were observed in the present study. Drogoul et al. (2000) used fistulated horses and observed increases in the MRT of the particulate phase of digesta of 37.2 hours to 47.2 hours when the physical form of diet was changed from chopped to ground or pelleted, respectively. In the present study, there was no detectable effect of reducing the particle size on the passage of the particulate phase. Other factors could affect the observed kinetics. For example, Clauss et al. (2014) reported increases in the MRT of the particulate phase when the grass hay intake was reduced. Additionally, these authors recorded differences in the MRT when horses were fed ad libitum with grass hay diets with distinct nutritional compositions, reporting values of $23 \mathrm{~h}$ for the best quality hay and $31 \mathrm{~h}$ for that with the poorest quality. In the present study, the diet was fixed, with the horses being fed at a rate of $2.5 \% \mathrm{BW}$, and an MRT of $36.7 \mathrm{~h}$ was obtained. Miyaji et al. (2014) fed horses

Table 3 - Mean values and standard deviation of the mean retention time (MRT), passage rate $(k)$ and transit time (TT) of the solid phase in horses fed coastcross hay subjected to different degrees of particle size reduction.

\begin{tabular}{lcccccc}
\hline \multirow{2}{*}{ Variables } & \multicolumn{7}{c}{ Coastcross hay } \\
\cline { 2 - 7 } & Long & $\begin{array}{c}\text { Chopped } \\
(5 \mathrm{~cm})\end{array}$ & $\begin{array}{c}\text { Ground } \\
(5 \mathrm{~mm})\end{array}$ & $\begin{array}{c}\text { Ground } \\
(3 \mathrm{~mm})\end{array}$ & Mean & CV (\%) \\
\hline MRT (hours) & $35.61 \pm 1.54$ & $36.39 \pm 1.04$ & $36.47 \pm 1.13$ & $38.60 \pm 2.05$ & 36.76 & 5.5 \\
k (h $\left.{ }^{-1}\right)$ & $2.81 \pm 0.12$ & $2.75 \pm 0.08$ & $2.74 \pm 0.09$ & $2.59 \pm 0.13$ & 2.72 & 5.3 \\
TT (hours) & 19 & 18 & 17 & 19 & 18.2 & 12.3 \\
\hline
\end{tabular}



Figure 2 - Cumulative chromium excretion (expressed as the percentage of total $\mathrm{Cr}$ excreted) in horses fed coastcross hay subjected to different degrees of particle size reduction. 
exclusively with a grass hay diet at $2.0 \%$ (high intake) or $1.3 \% \mathrm{BW} /$ day (low intake) and observed increases in the total MRT with reduced DM intake, reporting values for the particulate total MRT of 24.7 and $34.4 \mathrm{~h}$, respectively.

A significant difference in kinetics was observed $(\mathrm{P}<0.05)$ between the particulate and solute phases of digesta. The solute phase was faster, regardless of the degree of hay grinding (Table 4).

The solute phase flows through the ventral and dorsal colon faster than the particulate phase because a retention mechanism present in colon hinders the solid particle flow, which explains the differences between the phases of digesta (Argenzio et al., 1974, Pearson; Merritt, 1991; Drogoul et al., 2000; Oliveira et al., 2003; Van Weyenberg et al., 2006; Clauss et al., 2014; Miyaji et al., 2014).

There are factors that are not associated with the diet that can affect the passage of digesta (Van Weyenberg et al., 2006). Such factors may be associated with the animals themselves, such as their body weight and physiological condition, or with the adopted methodology, the type of marker, the frequency of feces collection or the mathematical models applied to estimate kinetic parameters.

In addition, the presence of a cannula in the right ventral colon in all of the experimental animals may have altered the pattern of passage kinetics and contributed to the observed disparities among studies and the difficulty of detecting the effect of reducing the particle size of roughage on the transit of digesta. According to Drogoul et al. (2000), there are differences in the passage of markers used to determine the MRT in intact horses compared with horses fistulated in the right ventral colon. These authors suggested that due to the site of the cannula, the capacity of the large intestine to select and retain larger particles was reduced when a physically modified diet was supplied. Such an effect might explain why no influence of the particle size on passage kinetics was detected, as the retention mechanisms in the ventral colon segment (Drogoul et al. 2000) might have been altered, preventing the segregation and selective retention of particles. The effect of a cannula in the cecum was evaluated by AutsbØ and Volden (2006), who observed the transit of digesta first in intact horses and after surgery and reported an increased MRT in fistulated animals.

The obtained particulate-to-solute marker $(\mathrm{Cr}-$ NDF/Co-EDTA) ratios were 1.16, 1.16, 1.23 and 1.23 for long hay, chopped hay, hay ground to $5 \mathrm{~mm}$ and hay ground to $3 \mathrm{~mm}$, respectively. According to Drogoul et al. (2000) the ratio tends to be the same, i.e., close to $1 / 1$, when ground pelleted hay is provided as feed. The results reported here did not indicate differences regarding passage kinetics, showing that under the applied experimental conditions, there was no effect of grinding on the ratio of the markers. The selectivity factor was also evaluated by Clauss et al. (2014), who observed no difference in the $\mathrm{MRT}_{\mathrm{Cr}} / \mathrm{MRT}_{\mathrm{Co}}$ ratio, even under a low hay intake in horses. The pattern of marker excretion described by Drogoul et al. (2000) appears to be associated with horses subjected to multiple fistulation that have had their "Colonic Separation Mechanism" impaired. Regarding the physicochemical characteristics of the digesta in the right ventral colon, differences were only observed in NDF and the mean particle size (Table 5).

Wolter et al. (1978) evaluated the variation in the dry matter content of cecum digesta during an 11-hour interval after supplying a complete diet in pelleted, extruded or semi-expanded form to horses fistulated in the colon.

Table 4 - The mean retention time (MRT), passage rate $(k)$ and transit time (TT) of the particulate and solute phases of digesta in horses fed coastcross hay subjected to different degrees of particle size reduction.

\begin{tabular}{ccccccc}
\hline \multirow{2}{*}{ Parameter } & Phases & Long & $\begin{array}{c}\text { Chopped } \\
(5 \mathrm{~cm})\end{array}$ & Ground (5 mm) Ground (3 mm) & Mean \\
\cline { 3 - 6 } & & $35.61^{\mathrm{a}}$ & $36.39^{\mathrm{a}}$ & $36.47^{\mathrm{a}}$ & $38.60^{\mathrm{a}}$ & $36.77^{\mathrm{a}}$ \\
\hline MRT (hours) & Solid & $30.62^{\mathrm{b}}$ & $31.17^{\mathrm{b}}$ & $29.70^{\mathrm{b}}$ & $31.37^{\mathrm{b}}$ & $30.72^{\mathrm{b}}$ \\
& Liquid & $2.81^{\mathrm{b}}$ & $2.75^{\mathrm{b}}$ & $2.74^{\mathrm{b}}$ & $2.05^{\mathrm{b}}$ & $2.73^{\mathrm{b}}$ \\
\multirow{3}{*}{$k\left(\mathrm{~h}^{-1}\right)$} & Solid & $3.28^{\mathrm{a}}$ & $3.24^{\mathrm{a}}$ & $3.39^{\mathrm{a}}$ & $3.19^{\mathrm{a}}$ & $3.28^{\mathrm{a}}$ \\
& Liquid & $19^{\mathrm{a}}$ & $18^{\mathrm{a}}$ & $17^{\mathrm{a}}$ & $19^{\mathrm{a}}$ & $18.25^{\mathrm{a}}$ \\
& Solid & $10^{\mathrm{b}}$ & $10^{\mathrm{b}}$ & $13^{\mathrm{b}}$ & $13^{\mathrm{b}}$ & $11.50^{\mathrm{b}}$ \\
\hline
\end{tabular}

Means followed by different letters in the columns differ for each parameter by the $\mathrm{F}$ test $(\mathrm{P}<0.05)$. 
Table 5 - Physicochemical characteristics of the right ventral colon digesta from horses fed coastcross hay subjected to different degrees of particle size reduction.

\begin{tabular}{ccccccc}
\hline & \multicolumn{7}{c}{ Coastcross hay } \\
\cline { 2 - 7 } Nutrients & Long & $\begin{array}{c}\text { Chopped } \\
(5 \mathrm{~cm})\end{array}$ & $\begin{array}{c}\text { Ground } \\
(5 \mathrm{~mm})\end{array}$ & $\begin{array}{c}\text { Ground } \\
(3 \mathrm{~mm})\end{array}$ & Mean & CV\% \\
\hline $\mathrm{DM}^{1}(\%)$ & $7.16 \pm 1.07$ & $6.90 \pm 1.26$ & $6.41 \pm 0.59$ & $5.52 \pm 1.06$ & 6.50 & 15.8 \\
$\mathrm{OM}^{2}(\%)$ & $84.83 \pm 2.63$ & $83.45 \pm 1.43$ & $83.38 \pm 1.11$ & $80.86 \pm 3.07$ & 83.13 & 3.1 \\
$\mathrm{CP}^{3}(\%)$ & $11.05 \pm 0.27$ & $12.58 \pm 1.60$ & $10.86 \pm 2.25$ & $12.61 \pm 1.91$ & 11.78 & 9.6 \\
$\mathrm{NDF}^{4}(\%)$ & $65.17 \pm 1.71^{\mathrm{a}}$ & $58.42 \pm 4.61^{\mathrm{ab}}$ & $64.49 \pm 2.65^{\mathrm{a}}$ & $53.46 \pm 3.53^{\mathrm{b}}$ & - & 6.4 \\
$\mathrm{ADF}^{5}(\%)$ & $33.64 \pm 0.76$ & $30.94 \pm 5.17$ & $33.34 \pm 1.04$ & $28.53 \pm 1.56$ & 31.62 & 9.4 \\
$\mathrm{pH}$ & 7.0 & 7.1 & 7.1 & 7.2 & 7.1 & 2.9 \\
$\mathrm{MPS}^{6}(\mathrm{~mm})$ & $0.64^{\mathrm{a}}$ & $0.61^{\mathrm{a}}$ & $0.55^{\mathrm{ab}}$ & $0.51^{\mathrm{b}}$ & - & \\
\hline
\end{tabular}

Means followed by different letters on the lines differ by the SNK test (5\%): ${ }^{1} \mathrm{DM}$ : Dry matter; ${ }^{2} \mathrm{OM}$ : organic matter, ${ }^{3} \mathrm{CP}$ : crude protein, ${ }^{4} \mathrm{NDF}$ : neutral detergent fiber, ${ }^{5} \mathrm{ADF}$ : acid detergent fiber, ${ }^{6} \mathrm{MPS}$ : mean particle size.

These authors did not observe an effect of the diet on dry matter contents, and the amplitude of variation recorded was 5.4 to $9.4 \%$ DM. The dry matter contents observed in the present study among the diets subjected to different degrees of grinding was 5.5 to $7.16 \%$, similar to the values reported by Wolter et al. (1978).

There were no significant differences $(\mathrm{P}>0.05)$ in the crude protein contents of colon digesta of the horses, with 11.0 to $12.6 \% \mathrm{CP}$ being recorded. According to Bjornhag (1987), it is possible that the nitrogen contents of the proximal colon show differences due to selective particle retention.

Differences were observed in the NDF contents of the right ventral colon, with the lowest NDF value of 53.4\% being obtained for $3 \mathrm{~mm}$ ground hay. Previous results from our research team indicated no differences due to particle size reduction regarding the total dry matter content and NDF digestibility coefficient of a grass hay diet, with values of $60,3 \%$ and $63,1 \%$ being recorded, respectively (Pimentel et al., 2009). Therefore, the reduced NDF values observed in the present study cannot be associated with increases in digestibility as expected. Additionally, the low NDF content observed can be attributed to the impairment of the colonic separation mechanism, as such separation does not occur effectively for small solid particles, which could affect the composition of the right ventral digesta.

Additionally, fiber presents certain physicochemical properties, such as its solubility, particle size, hydration capacity and viscosity (Potty, 1996), and smaller-sized particles increase the water retention capacity (Hill, 2007). One hypothesis for explaining the increased transit time of the solute phase is that some physical properties of fiber can be altered by mechanical processes, and we suggest that the great reduction of particle size helped to increase the association of small particles with the solute phase, which would increase the viscosity of the digesta and affect its transit time.

Argenzio et al. (1974) collected digesta from the right ventral colon of horses fed complete pelleted diets consisting of hay and grains or that were rich in fiber and observed a pH ranging from 6.0 to 6.5 .

The high proportion of $0.51 \mathrm{~mm}$ (MPS) small particles in the diet exceeded the particle reduction capacity associated with normal chewing in horses fed exclusively a hay diet, where a value of $0.64 \mathrm{~mm}$ was observed. Clauss et al. (2014) fed horses ad libitum exclusively with a grass hay diet with a specific nutritional quality and observed that the horses chewed hay with a higher NDF content more intensively, which altered the average size of fecal particles. This finding confirms that under the normal conditions in which hay is supplied, horses naturally reduce the hay particle size to between 1.17 to $0.74 \mathrm{~mm}$ (Clauss et al., 2014). Furthermore, the selective retention mechanisms related to particles present in the cecum (Sellers et al., 1982) in the right ventral colon and at the junction of the ventral and dorsal colon (Argenzio et al., 1974; Drogoul et al., 2000) would also be affected due to the smaller particle size.

Food processing helps to break structures. However, it is important maintain an adequate particle size to allow the digestive tract to continue to function normally. Methods for the identification of physical effective fiber have been developed for ruminants. But there is little information available to verify the applicability of this 
theory to horse nutrition. Horse nutritionists should most likely consider the effect of maintaining the chew rate and normal digestive tract motility in the formulation of diets.

It is difficult to compare the results of different studies because previous observations have shown that there are many factors associated with the regulation of passage kinetics, including the species involved, their live weight and intake level and food quality (Udén et al., 1982; Bjornhag, 1987; Pearson; Merritt, 1991; Clauss et al., 2014) as well as the markers used and the technique applied for quantification (Moore-Colyer et al., 2003; Van Weyenberg et al., 2006).

\section{CONCLUSIONS}

The grinding of hay altered the kinetics of the passage of the solute phase, increasing the transit time. However, it did not alter the kinetics of the particulate phase or intestinal $\mathrm{pH}$. Regardless of the hay particle size, the mean retention time and transit time of the solute phase in the digestive tract of horses were longer than those of the liquid phase. Grinding hay reduced the average particle size in the right ventral colon.

\section{ACKNOWLEDGEMENT}

Carlos Chagas Filho Foundation for research in Rio de Janeiro State (FAPERJ) for financial support.

\section{REFERENCES}

AMERICAN DAIRY SCIENCE ASSOCIATION - ADSA. A report: committee on classification of particle size in feedstuffs. Journal Dairy Science. 53(5):689-690, 1970.

ARGENZIO, R. A. et al. Digesta passage and water exchange in the equine large intestine. American Journal of Physiology. 226(5):1035-1042, 1974.

\section{ASSOCIATION OF OFFICIAL ANALYTICAL} CHEMISTS - AOAC. Official methods of analysis, 16. ed. Airlington: AOAC Internacional, 1995. 1025p.

AUTSBØ, D.; VOLDEN, H. Influence of passage model and cecal cannulation on estimated passage kinetics of roughage and concentrate in the gastrointestinal tract of horses. Livestock Science.100:33-43, 2006.

BJORNHAG, G. Comparative aspects of digestion in the hindgut of mammals. The Colonic Separation Mechanism (CSM). Deutsche Tierärtzliche Wochenschrift. 94(8):33-36, 1987.
BOLIN, D.W.; KING, R.P. A simplified method for determination of $\mathrm{Cr}_{2} \mathrm{O}_{3}$ when used as an indicator. Science.116:634, 1952.

CLAUSS, M. et al. The effect of very low food intake on digestive physiology and forage digestibility in horses. Journal of Animal Physiology and Animal Nutrition. 98:107-118, 2014.

CUDDEFORD, D.; WOODHEAD, A.; MUIRHEAD, R.H.A. comparison between the nutritive value of shortcutting cycle, high temperature-dried alfalfa and timothy hay for horses. Equine Veterinary Journal. 24(2):8489, 1992.

DROGOUL, C.; PONCET, C.; TISSERAND, J.L. Feeding ground and pelleted hay rather than chopped hay to ponies. 1. Consequences for in vivo digestibility and passage of digesta. Animal Feed Science and Technology. 87:117-130, 2000.

FISHER, D.S.; BURNS, J.C.; POND, K.C. Estimation of mean and median particle size of ruminant digesta.

Journal of Dairy Science.71:518-524, 1988.

FAICHNEY, G.J. The use of markers to partition digestion within the gastrointestinal tract of ruminants.

In: Digestion and Metabolism in Ruminant. McDONALD, I.W., WARNER, A. I.C. (Eds). The University of New England Publishing Unit, Armidale, NSW, p.277-291, 1975.

HILL, J. Impacts of nutritional technology on feeds offered to horses: A review of effects of processing on voluntary intake, digesta characteristics and feed utilization. Animal Feed Science and Technology. 138:92-117, 2007.

KIMURA, F.T.; MILLER, V.L. Improved determination of chromic oxide in cow feed and feces. Agricultural Food Chemistry. 5:216-217, 1957.

LOWE, J.E.; HINTZ, H.F.; SCHRYVER, H.F.A. New technique for long-term cecal fistulation in ponies. American Journal of Veterinary Research. 31(6):1109-1111, 1970.

MIYAJI, M. et al. Effect of grass hay intake on fiber digestion and digesta retention time in the hindgut of horses. Journal Animal Science. 92:1574-1581, 2014. 
MOORE-COLYER, M.J.S.; MORROW, H.J.; LONGLAND, A.C. Mathematical modeling of digesta passage rate, mean retention time and in vivo apparent digestibility of two different lengths of hay and big-bale grass silage in ponies. British Journal of Nutrition. 90:109-118, 2003.

NATIONAL RESEARCH COUNCIL, Nutrient requirement of horses, Washington: National Academy Press, 2007, 6. Ed, 341p.

OLIVEIRA, C.A.A. et al. Kinetics of passage of digesta and water and nitrogen balance in horses fed diets with different ratios of roughage and concentrate. Brazilian Journal of Animal Science. 32(1):140-149, 2003.

PEARSON, R.A.; MERRIT, J.B. Intake, digestion and gastrointestinal transit in resting donkeys and ponies and exercised donkeys given ad libitum hay and straw diets. Equine Veterinary Journal. 23(5):339-343, 1991.

PIMENTEL, R.R.M. et al. Intake, apparent nutrient digestibility and water balance in horses fed on different forms of coast-cross hay. Brazilian Journal of Animal Science. 38(7):1272-1278, 2009.

POTTY, V. H. Physico-chemical aspects, physiological functions, nutritional importance and technological significance of dietary fibres - A Critical Appraisal. Journal of Food Science Technology. 33(1):1-18, 1996.
SELLERS, A.F. et al. Retropulsion-propulsion in equine large colon. American Journal of Veterinary Research. 43(3):390-396, 1982.

SMITH, L.W.; WALDO, D.R. Method for sizing forage cell wall particle. Journal of Dairy Science. 52(8):2051-2053, 1969.

UDÉN, P.; ROUNSAVILLE, T.R.; WIGGANS, G.R. The measurement of liquid and solid ingesta retention in ruminants, equine and rabbits given timothy (Phleumpratense) hay. British Journal of Nutrition. 48(2):329-339, 1982.

VAN SOEST, P.J.; ROBERTSON, J.B.; LEWIS, B.A. Methods for dietary fiber, neutral detergent fiber, and non-starch polysaccharides in relation to animal nutrition. Journal Dairy Science. 74(10):3583-3597, 1991.

VAN WEYENBERG, S.V.; SALES, J.; JANSSENS, G.P.J. Passage rate of digesta through the equine gastrointestinal tract: A review. Livestock Production Science. 99(1):3-12, 2006.

VANDER NOOT, G.W. et al. Rate of passage of various feedstuffs through the digestive tract of horses. Journal of Animal Science. 26:1309-1311, 1967.

WOLTER, R. et al. Digestibilité et activité biochimique intracaecal e chez le poney recevant un même alimet complet présenté sous forme granulée, expansée ou semiexpansée. Annales du Zootechnie. 27(1):47-60. 1978. 